\title{
ORGANIC MATTER LABILE FRACTIONS AND CARBON STOCKS IN A TYPIC QUARTZIPSAMMENT CULTIVATED WITH SUGARCANE HARVESTED WITHOUT BURNING ${ }^{1}$
}

\author{
JOSÉ DE SOUZA OLIVEIRA FILHO², MARCOS GERVASIO PEREIRA ${ }^{3 *}$, BOANERGES FREIRE DE AQUINO²
}

\begin{abstract}
The permanence of sugarcane straw on the soil surface, in systems without the pre-harvest straw burning practice, directly affects the soil organic matter dynamics. The objective of this work was to evaluate the changes in total organic carbon (TOC), carbon in the light organic matter (CLOM) and particulate organic carbon (POC), and their carbon stocks in a typic Quartzipsamment cultivated for nine years with sugarcane crops, which were conducted without the pre-harvest straw burning practice, in Paraipaba, State of Ceará, Brazil. Disturbed and undisturbed soil samples were collected at depths of 0.0-0.025, 0.025-0.05, $0.05-0.10,0.10-0.20$ and $0.20-0.30 \mathrm{~m}$, in the sugarcane crop area and in an adjacent native forest area, in order to quantify the TOC, CLOM and POC, as well as the carbon stocks accumulated in the layer $0.0-0.30 \mathrm{~m}$ related to these fractions (TOCSt, CLOMSt and POCSt). TOC content changes after nine years of sugarcane crops, conducted without pre-harvest straw burning, were found only in the layers $0.10-0.20$ and $0.20-0.30 \mathrm{~m}$. The CLOM varied only in the layer $0.025-0.05 \mathrm{~m}$. The POC content changes were more noticeable than the changes in TOC and CMOL. The CLOM of the sugarcane crop area presented high similarity with TOC, which may affect their quantification in studies related to the soil organic matter dynamics. The sugarcane crop increased the TOCSt, POCSt and CLOMSt in the layer 0.0-0.30 m, compared with the adjacent native forest area.
\end{abstract}

Keywords: Light organic matter. Particulate organic carbon. Sandy soil.

\section{FRAÇÕES LÁBEIS DA MATÉRIA ORGÂNICA E ESTOQUES DE CARBONO EM NEOSSOLO QUARTZARÊNICO CULTIVADO COM CANA-DE-AÇÚCAR COLHIDA SEM QUEIMA}

RESUMO - A permanência da palhada da cana-de-açúcar sobre a superfície do solo no sistema sem queima do canavial tem influência direta na dinâmica da matéria orgânica desses solos. Objetivou-se com este estudo avaliar as mudanças ocorridas nos conteúdos de carbono orgânico total (COT), carbono da matéria orgânica leve (CMOL) e carbono orgânico particulado (COP) e em seus respectivos estoques de carbono em um Neossolo Quartzarênico após nove anos de cultivo com cana-de-açúcar sem queima prévia do canavial em Paraipaba-CE. Foram coletadas amostras de solo deformado e indeformado nas profundidades de $0,0-0,025$; $0,025-0,05 ; 0,05-0,10 ; 0,10-0,20$ e $0,20-0,30 \mathrm{~m}$ em uma área sob cultivo de cana-de-açúcar e em uma área de mata nativa adjacente, quantificando-se os teores de COT, CMOL e COP, assim como os valores de estoques de carbono acumulados na camada de $0-0,30 \mathrm{~m}$ associados a essas frações: EstCOT, EstCMOL e EstCOP. Mudanças no conteúdo de COT após nove anos de cultivo de cana-de-açúcar sem queima foi observado apenas nas camadas de $0,10-0,20$ e $0,20-0,30 \mathrm{~m}$. Já o CMOL apresentou variação apenas para a camada de $0,025-0,05 \mathrm{~m}$. As mudanças ocorridas no conteúdo de COP foram mais perceptíveis do que no conteúdo de COT e CMOL. O CMOL na área de cana apresentou uma elevada similaridade com o COT, o que pode tornar inviável sua quantificação em estudos para inferir sobre a dinâmica da matéria orgânica em solos. O cultivo de cana-de-açúcar aumentou o EstCOT, o EstCOP e o EstCMOL na camada de $0-0,30 \mathrm{~m}$ em comparação a área de mata nativa adjacente.

Palavras-Chave: Matéria orgânica leve. Carbono orgânico particulado. Solo arenoso.

\footnotetext{
*Corresponding author

${ }^{1}$ Received for publication in $11 / 13 / 2014$; accepted in 08/04/2016.

Paper extracted from the master thesis of the first author.

${ }^{2}$ Departament of Soil Science, Universidade Federal do Ceará, Fortaleza, CE, Brazil; jfilhomesti@hotmail.com, aquino@ufc.br.

${ }^{3}$ Department of Soil, Universidade Federal Rural do Rio de Janeiro, Seropédica, RJ, Brazil; mgervasiopereira01@gmail.com.
} 


\section{INTRODUCTION}

The mechanized harvesting system of sugarcane leaves all crop residues on the soil surface, keeping it covered for a long time. Studies show that about $10 \mathrm{Mg} \mathrm{ha}^{-1}$ per year of straw are left on the soil surface, contributing to the improvement of soil fertility (RESENDE et al., 2006; LUCA et al., 2008; SILVA NETO et al., 2013).

The permanence of the sugarcane straw on the soil surface provides significant increases in the soil organic matter content (SOM), especially in the more clayey soils (LUCA et al., 2008; CERRI et al., 2011). According to Dick et al. (2009), clayey soils tend to have high organic matter stocks than sandy soils, due to its high organomineral interactions and low mineralization rates. Therefore, considering the reduced potential for organic matter accumulation of sandy texture soils (FRAZÃO et al., 2010; MUJURU et al., 2013), different management systems must be used to maximize the organic matter supply and maintenance in these soils.

The total organic carbon (TOC) stands out among the attributes used to monitor the impacts of agricultural practices on the SOM dynamics. However, some authors reported that, depending on how long a particular management system was implemented, the TOC is not suitable to detect changes in SOM content depending on land use (LEITE et al., 2003; CONCEIÇÃO et al., 2005; SOUZA et al., 2006). Roscoe and Machado (2002) suggested the study of the SOM physical fractions in order to identify such changes. The carbon in the light organic matter (CLOM) and the particulate organic carbon (POC) stand out among these fractions.

The light organic matter (LOM) is an active fraction of the SOM consisted of organic residues at different decomposition stages, which may present intact tissues that have low residence time in the soil depending on the recalcitrance of the original material (JANZEN et al., 1992). This fraction is quantified by the flotation of organic materials in a liquid medium. Pereira et al. (2010) used water, due to its simplicity and economy, after dispersion with sodium hydroxide (ANDERSON; INGRAN, 1989), to separate, by flotation, the LOM of soil samples from areas of the Cerrado biome under no-tillage, in Minas Gerais, Brazil. According to He et al. (2008) and Nascente et al. (2013), the quantification of the CLOM is efficient to identify changes in the organic matter content depending on land use.

The POC is a fraction of the SOM found after the dispersion of soil granulometric fractions (sand, silt and clay) in a $53 \mu \mathrm{m}$-mesh sieve. The POC, similarly to the LOM, consists of materials that still have intact tissues, such as leaves and roots pieces, and have high decomposition rate (CAMBARDELLA; ELLIOT, 1992). According to Bayer et al. (2004) and Rossi et al. (2012), the POC is more suitable to the determination of changes in the SOM content compared with the TOC.

POC and LOM are assessed by different ways, but they have the same functions and origins in the soil (ROSCOE; MACHADO, 2002). The dependence on CLOM and POC values related to the TOC content in the soil, and the existence or not of similarity in the dynamics of these fractions, must be considered to identify the fraction that best represents the dynamics of the SOM in sugarcane agroecosystems.

In this context, the objective of this work was to evaluate the changes in TOC, CLOM and POC contents and their carbon stocks, in a typic Quartzipsamment cultivated for nine years with sugarcane crops, which were conducted without the pre-harvest straw burning practice, using an adjacent native forest area as reference, in the semiarid region of the State of Ceará, Brazil.

\section{MATERIAL AND METHODS}

The experiment was conducted in an area that had commercial sugarcane crops (variety SP 716949) for nine years, which were conducted without the pre-harvest straw burning practice, located in Paraipaba, State of Ceará, Brazil $\left(3^{\circ} 30^{\prime} 08^{\prime \prime} \mathrm{S}\right.$, $39^{\circ} 12^{\prime} 68^{\prime \prime} \mathrm{W}$ and $26 \mathrm{~m}$ of altitude). The region climate is tropical semiarid, with precipitation unevenly distributed in the first half of the year and high concentrated from January to May. It has annual average temperature of $27^{\circ} \mathrm{C}$ and average relative humidity around $80 \%$ (IPECE, 2013).

Two $1 \mathrm{~m}$-deep trenches were opened in the sugarcane crop area and in the adjacent native forest area for soil classification. The soils of the two areas were classified as a typic orthic Quartzarenic Neosol (typic Quartzipsamment) (SANTOS et al., 2013). The chemical and physical attributes of the soils of each area are shown in Table 1.

Samplings were carried out in September, 2011 , in a $20 \times 25 \mathrm{~m}$ area of the sugarcane crop, as well as to the adjacent native forest area. Six mini trenches (replicates) were opened (depth of $0.30 \mathrm{~m}$ ) randomly in each area. Disturbed and undisturbed soil samples were collected at depths of $0.0-0.025$, $0.025-0.05,0.05-0.10,0.10-0.20$ and $0.20-0.30 \mathrm{~m}$ in both areas. The disturbed samples were dried, disaggregated and sieved in a $2 \mathrm{~mm}$-mesh sieve in order to obtain the air-dried ground soil (ADGS). Undisturbed samples were taken with a Kopecky ring for density determination and carbon stock calculations.

The total organic carbon (TOC) was determined by oxidation of the organic matter by potassium dichromate $0.167 \mathrm{~mol} \mathrm{~L}^{-1}$ in a sulfuric acid medium and through titration by ferrous ammonium sulfate $0.2 \mathrm{~mol} \mathrm{~L}^{-1}$ (YEOMANS; BREMNER, 1988). 
Table 1. Chemical and physical attributes in the layer 0.0-1.0 $\mathrm{m}$ of a typic Quartzipsamment under a sugarcane crop and its adjacent native forest area.

\begin{tabular}{|c|c|c|c|c|c|c|c|c|c|c|}
\hline \multirow[t]{2}{*}{ Depth (m) } & $\mathrm{pH}$ & $\mathrm{Ca}$ & $\mathrm{Mg}$ & $\begin{array}{l}\mathrm{Na} \\
\mathrm{Cmol}_{\mathrm{c}}\end{array}$ & $\begin{array}{c}\mathrm{K} \\
\mathrm{n}^{-3}---\end{array}$ & $\begin{array}{l}\mathrm{H}+\mathrm{Al} \\
----\end{array}$ & $\begin{array}{c}\mathrm{P} \text { available PP P } \\
\dot{m g ~ \mathrm{dm}^{-3}}\end{array}$ & Sand & $\begin{array}{l}\text { Silt } \\
\mathrm{g} \mathrm{kg}^{-1}\end{array}$ & $\begin{array}{l}\text { Clay } \\
----\end{array}$ \\
\hline & \multicolumn{10}{|c|}{ Sugarcane } \\
\hline $0-0.1$ & 6.0 & 2.4 & 1.1 & 0.0 & 0.0 & 0.7 & 4.0 & 850 & 50 & 100 \\
\hline $0.1-0.2$ & 6.4 & 2.1 & 1.0 & 0.0 & 0.0 & 1.7 & 2.0 & 800 & 90 & 110 \\
\hline $0.2-0.3$ & 6.5 & 1.2 & 0.8 & 0.1 & 0.0 & 1.2 & 1.0 & 780 & 90 & 130 \\
\hline $0.3-0.4$ & 6.8 & 1.2 & 0.8 & 0.1 & 0.0 & 1.2 & 1.0 & 780 & 110 & 110 \\
\hline $0.4-0.5$ & 6.7 & 1.0 & 0.5 & 0.1 & 0.0 & 1.2 & 1.0 & 760 & 50 & 190 \\
\hline $0.6-0.8$ & 6.6 & 0.5 & 0.5 & 0.1 & 0.0 & 1.2 & 1.0 & 760 & 100 & 140 \\
\hline \multirow[t]{2}{*}{$0.8-1.0$} & 6.0 & 0.5 & 0.5 & 0.1 & 0.0 & 1.5 & 1.0 & 760 & 130 & 110 \\
\hline & \multicolumn{10}{|c|}{ Forest } \\
\hline $0-0.1$ & 5.4 & 1.8 & 1.2 & 0.0 & 0.1 & 2.0 & 2.0 & 840 & 60 & 100 \\
\hline $0.1-0.2$ & 5.4 & 1.7 & 1.0 & 0.0 & 0.1 & 1.7 & 2.0 & 840 & 80 & 80 \\
\hline $0.2-0.3$ & 5.4 & 0.4 & 0.6 & 0.0 & 0.0 & 1.5 & 1.0 & 770 & 120 & 110 \\
\hline $0.3-0.4$ & 5.6 & 0.3 & 0.3 & 0.0 & 0.0 & 1.5 & 1.0 & 790 & 80 & 130 \\
\hline $0.4-0.5$ & 5.2 & 0.3 & 0.1 & 0.0 & 0.0 & 1.2 & 1.0 & 760 & 90 & 150 \\
\hline $0.6-0.8$ & 5.1 & 0.3 & 0.1 & 0.0 & 0.0 & 2.0 & 1.0 & 740 & 120 & 140 \\
\hline $0.8-1.0$ & 5.1 & 0.3 & 0.1 & 0.0 & 0.0 & 1.5 & 1.0 & 760 & 110 & 130 \\
\hline
\end{tabular}

$\mathrm{pH}$ values evaluated in water; contents of $\mathrm{Ca}, \mathrm{Mg}, \mathrm{Na}, \mathrm{K}, \mathrm{H}+\mathrm{Al}, \mathrm{P}$ available and granulometric fractions (sand, silt and clay contents) determined according to Silva (2009).

The light organic matter (LOM) was determined through the water flotation method (ANDERSON; INGRAM, 1989). Fifty grams $50 \mathrm{~g}$ of the ADGS were stirred in $100 \mathrm{~mL}$ of $\mathrm{NaOH}$ $0.1 \mathrm{~mol} \mathrm{~L}^{-1}$ for 12 hours and then sieved in a $0.25 \mathrm{~mm}$-mesh sieve to eliminate the clay. The material retained on the sieve (LOM and sand) was transferred to a Becker, water was added to it and the floated material (suspended) was sieved again in a $0.25 \mathrm{~mm}$-mesh sieve, carefully separating the LOM from the sand fraction. The material was dried at $60^{\circ} \mathrm{C}$ to a complete drying, and the carbon content of the fraction (CLOM) was determined according to Yeomans and Bremner (1988).

For the determination of particulate organic carbon (POC), $60 \mathrm{ml}$ of sodium hexametaphosphate $\left(5 \mathrm{~g} \mathrm{~L}^{-1}\right)$ were added to $20 \mathrm{~g}$ of ADGS, stirred for 16 hours in a horizontal shaker (CAMBARDELLA; ELLIOT, 1992). Then, the suspension was sieved in a $53 \mu \mathrm{m}$-mesh sieve using a waterjet to remove all the clay and silt. The material retained on the sieve (POC) associated with the sand fraction was dried at $60^{\circ} \mathrm{C}$ to measure its dry weight, and then ground in a mortar to determine the organic carbon content, according to Yeomans and Bremner (1988).

The calculation of accumulated carbon stocks in the soil (layer $0.0-0.30 \mathrm{~m}$ ), i.e., the stocks of total organic carbon (TOCSt), particulate organic carbon (POCSt) and carbon in the light organic matter (CLOMSt), was performed through the equation 1 (VELDKAMP, 1994),

$$
S t=\left(C * D_{S} * T h i\right) / 10
$$

where $S t$ is the TOC, POC or CLOM stock, expressed in $\mathrm{Mg} \mathrm{ha}{ }^{-1}$; $C$ is the TOC, POC or CLOM content, expressed in $\mathrm{Mg} \mathrm{ha}^{-1} ; D_{S}$ is the bulk density, expressed in $\mathrm{Mg} \mathrm{m}^{-3}$; and Thi is the thickness of each layer, expressed in $\mathrm{cm}$.

The accumulation of plant residue on the soil surface (PRS) was also quantified, using a PVC frame of $0.50 \times 0.50 \mathrm{~m}$. This frame was randomly thrown in the sugarcane evaluation area and in the adjacent native forest, with 6 replications, and all plant material within it was weighted. The values found were extrapolated to one hectare.

The data were subjected to the $\mathrm{t}$ test, at $5 \%$ probability, to identify differences between the variables of the two areas, using the statistical program Assistat 7.6 Beta (SILVA; AZEVEDO, 2002). Cluster analysis was performed to assess the similarities between the organic fractions in the different depths sampled, using the Euclidean distance as similarity coefficient between fractions in the software IBM PASW Statistics 18.0.

\section{RESULTS AND DISCUSSION}

The total organic carbon (TOC) contents tended to a decrease with the increase in depth in both areas evaluated (Table 2), with greater decreases in the native forest area. 
Table 2. Total organic carbon (TOC), particulate organic carbon (POC) and carbon in the light organic matter (CLOM) in different depths of a typic Quartzipsamment under a sugarcane crop and its adjacent native forest area.

\begin{tabular}{|c|c|c|c|c|c|}
\hline \multirow[t]{2}{*}{ Land use } & \multicolumn{5}{|c|}{ Depth (m) } \\
\hline & $0-0.025$ & $0.025-0.05$ & $0.05-0.10$ & $0.10-0.20$ & $0.20-0.30$ \\
\hline & \multicolumn{5}{|c|}{---o- } \\
\hline Sugarcane & $14.45 \mathrm{a}$ & $13.51 \mathrm{ab}$ & $12.62 \mathrm{a}$ & $12.78 \mathrm{a}$ & $12.63 \mathrm{a}$ \\
\hline \multirow[t]{2}{*}{ Forest } & $14.90 \mathrm{a}$ & $13.51 \mathrm{a}$ & $12.58 \mathrm{a}$ & $10.58 \mathrm{~b}$ & $9.58 \mathrm{~b}$ \\
\hline & \multicolumn{5}{|c|}{ - POC $\left(\mathrm{g} \mathrm{kg}^{-1}\right)$} \\
\hline Sugarcane & $7.31 \mathrm{a}$ & $7.73 \mathrm{a}$ & $7.60 \mathrm{a}$ & $7.38 \mathrm{a}$ & $7.20 \mathrm{a}$ \\
\hline \multirow[t]{2}{*}{ Forest } & $7.25 \mathrm{a}$ & $6.31 \mathrm{~b}$ & $6.51 \mathrm{~b}$ & $6.48 \mathrm{~b}$ & $6.36 \mathrm{~b}$ \\
\hline & \multicolumn{5}{|c|}{ 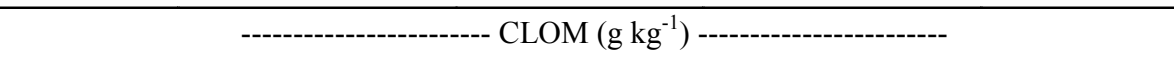 } \\
\hline Sugarcane & $4.28 \mathrm{a}$ & $4.41 \mathrm{a}$ & $4.24 \mathrm{a}$ & $4.25 \mathrm{a}$ & $4.20 \mathrm{a}$ \\
\hline Forest & $4.27 \mathrm{a}$ & $4.10 \mathrm{~b}$ & $4.15 \mathrm{a}$ & $4.17 \mathrm{a}$ & $4.13 \mathrm{a}$ \\
\hline
\end{tabular}

Means followed by the same letters in the rows do not differ by the $t$ test at $5 \%$ probability.

The TOC content of the two areas was not significantly different in the layers $0.0-0.025$, $0.025-0.05$ and $0.05-0.10 \mathrm{~m}$. This result was also reported by Souza et al. (2006), who evaluated the effect of different management systems on carbon accumulation in a typic Quartzipsamment of the Cerrado biome, Goiás, Brazil. According to these authors, the TOC is not suitable to evidence, in short term (10 years), changes in organic matter content as a function of soil management. The TOC content in the sugarcane crop area, considering the layer 0.0-0.30 $\mathrm{m}$, was higher than those found in several studies on sugarcane crops in systems with the pre-harvest straw burning practice (BLAIR, 2000; LUCA et al., 2008; PINHEIRO et al., 2010; THORBURN et al., 2012), denoting the beneficial effect of the management system used to the organic matter accumulation in the soil.

The TOC contents of the sugarcane crop area in the layers $0.10-0.20$ and $0.20-0.30 \mathrm{~m}$ were higher than those found in the adjacent native forest. The great input of decomposing plant material from the sugarcane root system at these depths may explain this result (PINHEIRO et al., 2010). Differences in TOC contents between the two areas was only visible, in general, in the soil subsurface layers, denoting the importance of considering these layers in decision-makings related to the soil management.

The contents of particulate organic carbon (POC) of both areas showed no significant difference in the layer $0.0-0.025 \mathrm{~m}$. However, in the other depths, it was always higher in the sugarcane area, compared with the native forest. The content of this fraction may decrease with time or increase, returning or surpassing the content found in natural conditions, depending on the management practices. This pattern was also observed by Galdos, Cerri and Cerri (2009). They reported that after eight years of sugarcane crops in systems without the pre-harvest straw burning practice, the soil POC contents showed the same initial level, i.e., similar to those found in the adjacent area under native vegetation, confirming the results found in the present work.

The carbon in the light organic matter (CLOM) was the variable that showed the lowest variation between the two areas, with differences only in the layer $0.025-0.05 \mathrm{~m}$. The second layer of the sugarcane area presented the highest contents of CLOM. Several studies emphasize the decrease of CLOM content in sandy soils subjected to conservationist management systems, in which previous crop residues remain on the soil surface, compared with native forest areas (SOUZA et al., 2006; FRAZÃO et al., 2010). However, this result was not found in the present work, in which the CLOM were not suitable to assess such changes.

According to the dendrograms developed (Figure 1), the similarity between the TOC and CLOM and POC fractions were not evidenced in the native forest area, indicating that the values of these fractions have little relation with each other. However, high similarity between the CLOM and TOC fractions were found in the layers $0.05-0.10$ and $0.10-0.20 \mathrm{~mm}$ of the sugarcane area. This result may indicate a high dependence of the CLOM fraction to TOC content in the soil of the sugarcane area. 

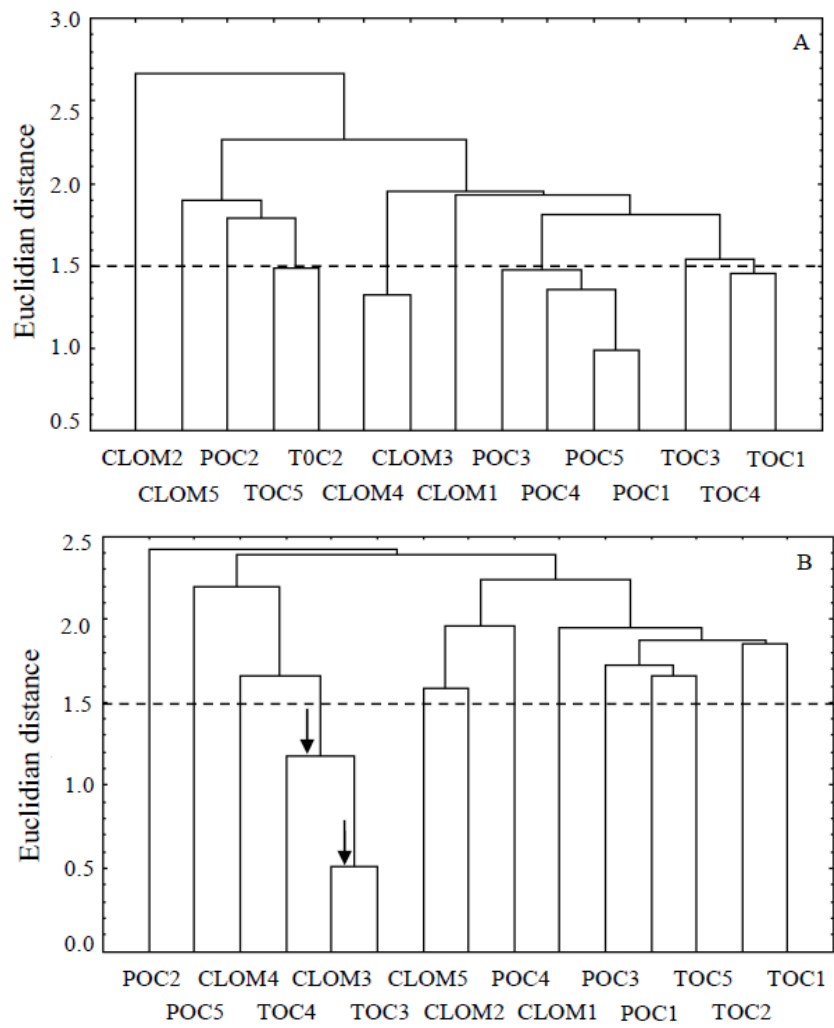

Figure 1. TOC and CLOM and POC similarities in the different soil depths, sampled in the native forest (A) and sugarcane crop (B) areas, established by the Euclidean distance. The depths are represented by the numbers $1(0.0-0.025 \mathrm{~m}), 2$ $(0.025-0.05 \mathrm{~m}), 3(0.05-0.10 \mathrm{~m}), 4(0.10-0.20 \mathrm{~m})$ and $5(0.20-0.30 \mathrm{~m})$ following the fraction acronyms. The arrows in the dendrogram of the area of sugarcane (B) indicate the group whose variables have high similarities.

The high similarity between CLOM and TOC may explain the low response of the CLOM to the identification of changes in organic matter between the two areas evaluated. However, Xavier et al. (2006) and Loss et al. (2010), evaluated the dynamics of CLOM in conservationist agricultural systems under constant input of organic matter to the soil surface, and reported that this fraction is important to diagnose changes in organic matter in those management systems.

All carbon fractions evaluated presented no difference between the two areas in the soil surface layer $(0.0-0.025 \mathrm{~m})$. This result can be explained by the significant effect of the plant material input to the soil surface in both areas, contributing to the increase of carbon content in the system (Figure 2).

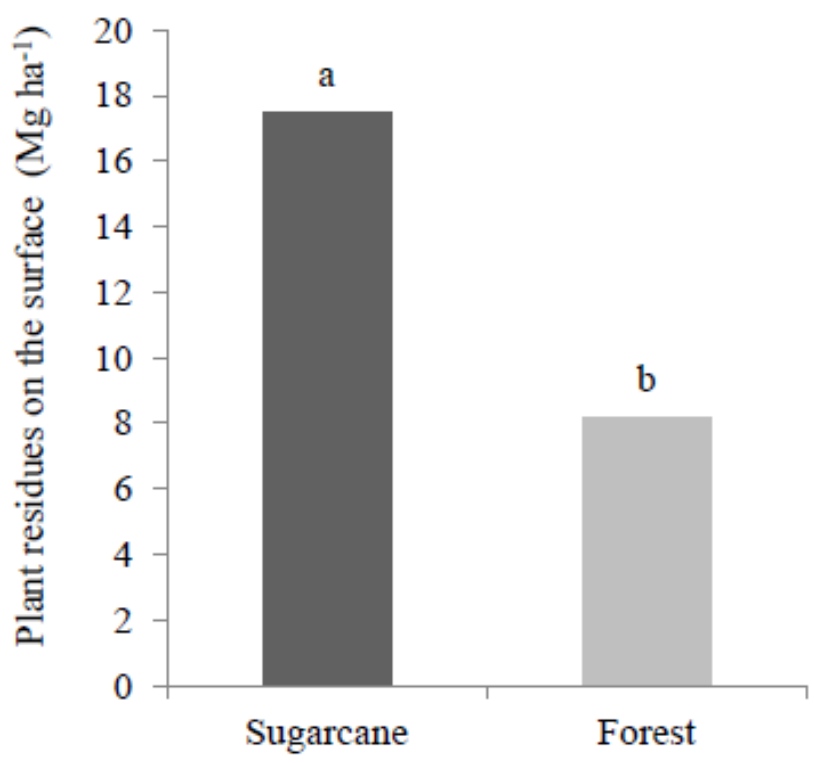

Figure 2. Accumulation of plant residues on the soil surface in the sugarcane crop area and in the adjacent native forest area. Different letters in the areas mean statistical difference by t test at $5 \%$ probability. 
The straw content on the soil surface of the sugarcane area was lower than that found by Luca et al. (2008), who found $40 \mathrm{Mg} \mathrm{ha}^{-1}$ in three crop cycles, conducted without the pre-harvest straw burning practice, in the State of São Paulo, Brazil. This difference in straw accumulation between the sugarcane areas is probably due to the effects of weather (lower temperature) and content of plant residues, since the yield in São Paulo $\left(74 \mathrm{Mg} \mathrm{ha}^{-1}\right)$ is higher than in Ceará $\left(50 \mathrm{Mg} \mathrm{ha}^{-1}\right)$ (CONAB, 2013). On the other hand, the adjacent native forest area presented values of plant material accumulation on the soil surface over $8 \mathrm{Mg} \mathrm{ha}^{-1}$, which is significantly higher compared with other studies on plant material accumulation on the soil surface in the Caatinga biome (COSTA et al., 2007; ANDRADE et al., 2008).

The bulk density ranged from 1.22 to $1.53 \mathrm{Mg} \mathrm{m}^{-3}$, with the highest values in the sugarcane crop area (Figure 3). Considering the average of the five depths evaluated in each area, the effect of machinery traffic in the sugarcane area increased the bulk density values by about $15 \%$, compared with those found in the adjacent native forest area.

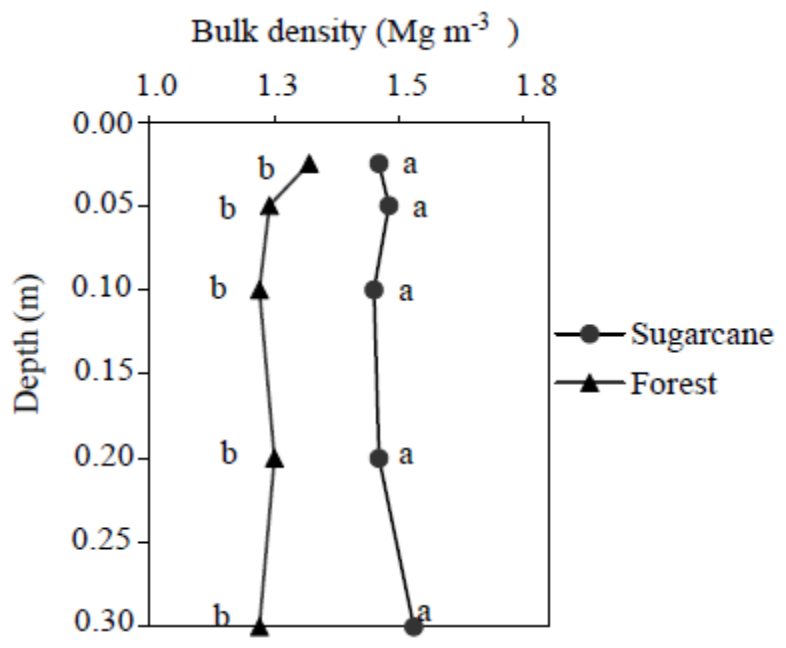

Figure 3. Mean values of bulk density as a function of depth in a typic Quartzipsamment under sugarcane crop and native forest. Means followed by the same letters, comparing the areas, do not differ by t test at $5 \%$ probability.

The total organic carbon stocks (TOCSt) found in the sugarcane area was higher than those found in the adjacent native forest area (Figure 4). The results showed greater carbon accumulation compared with results of other works developed in sugarcane agroecosystems (LUCA et al., 2008; CERRI et al., 2011).

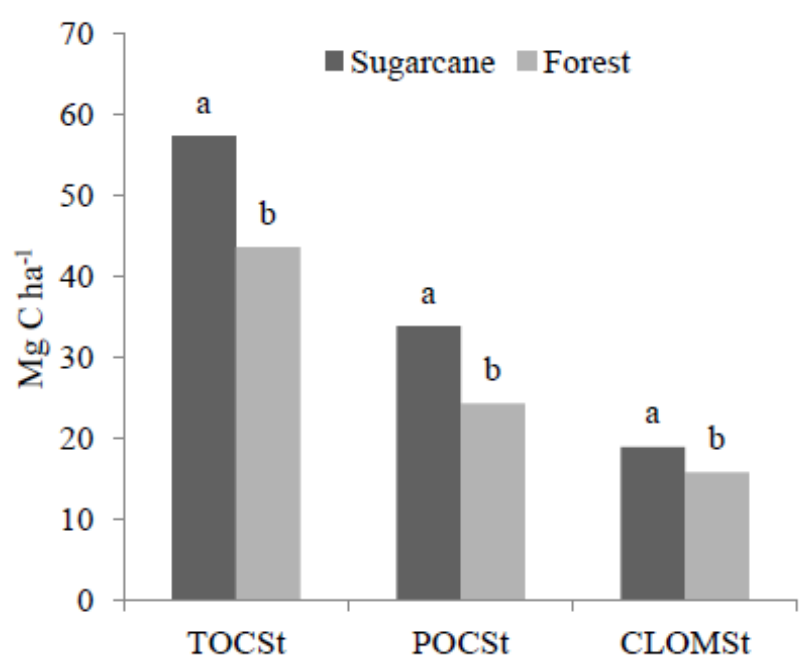

Figure 4. Stocks of total organic carbon (TOCSt), particulate organic carbon (POCSt) and of carbon in the light organic matter (CLOMSt) in the layer 0.0-0.30 m of a typic Quartzipsamment under sugarcane crop and native forest areas. Different letters in the areas mean statistical difference by the $t$ test at $5 \%$ probability. 
The POCSt and CLOMSt values were also higher in the area under sugarcane crop, which were affected by their higher bulk density values. These results differ from those found by Frazão et al. (2010), who reported higher CLOMSt values in the native forest area, compared with areas under different management systems, in Comodoro, Mato Grosso, Brazil. According to these authors, crop systems usually have more favorable conditions for microbial activity due to their higher moisture and soil fertility, promoting a better decomposition and reducing the contents of organic matter.

\section{CONCLUSIONS}

The cultivation of sugarcane for nine years, conducted without the pre-harvest straw burning practice, increased the total organic carbon (TOC) contents in the layers $0.10-0.20$ and $0.20-0.30 \mathrm{~m}$ due to the effect of organic material input by the decomposition of the crop root systems. On the other hand, the contents of carbon in the light organic matter (CLOM) showed variation only in the layer 0.025-0.05 m, compared with the adjacent native forest area.

The changes in the contents of particulate organic carbon (POC) were more noticeable, compared with the TOC and CLOM, showing the highest values in the sugarcane crop area, except for the top layer. Thus, this fraction is more suitable to the determination of changes in the soil organic matter content between the areas evaluated, compared with the TOC and CLOM.

The sugarcane crop, conducted without the pre-harvest straw burning practice, promoted stock increases of $31.6 \%$ (TOCSt), 39.5\% (POCSt) and $20.2 \%$ (CLOMSt) in the soil layer $0.0-0.30 \mathrm{~m}$, compared with the adjacent native forest area.

\section{REFERENCES}

ANDERSON, J. M.; INGRAM, J. S. I. Tropical soil biology and fertility: a handbook of methods. Wallingford: CAB International, 1989. $171 \mathrm{p}$.

ANDRADE, R. L. et al. Deposição de serrapilheira em área de caatinga na RPPN Fazenda Tamanduá, Santa Teresa - PB. Revista Caatinga, Mossoró, v. 21, n. 2, p. 223-230, 2008.

BAYER, C. et al. Armazenamento de carbono em frações lábeis da matéria orgânica de um Latossolo Vermelho sob plantio direto. Pesquisa Agropecuária Brasileira, Brasília, v. 39, n. 7, p. 677-683, 2004.

BLAIR, N. Impact of cultivation and sugar cane green trash management on carbon fractions and aggregate stability for a Chromic Luvisol in Queensland, Australia. Soil and Tillage Research, Amsterdam, v. 55, n. 3, p. 183-191, 2000.

CONAB. Companhia Nacional de Abastecimento. Acompanhamento da safra brasileira: cana-deaçúcar, segundo levantamento. Disponível em: < http://www.conab.gov.br/OlalaCMS/uploads/ arquivos/14_08_28_08_52_35_boletim_cana_portug ues_-_2o_lev_-_2014-15.pdf $>$. Acesso em: 15 set. 2014 .

CAMBARDELLA, C. A.; ELLIOTT, E. T. Particulate soil organic - matter changes across a grassland cultivation sequence. Soil Science Society of American Journal, Madison, v. 56, n. 3, p. 777783, 1992.

CERRI, C. C. et al. Effect of sugarcane harvesting systems on soil carbon stocks in Brazil: an examination of existing data. European Journal of Soil Science, Malden, v. 62, n. 1, p. 23-28, 2011.

CONCEIÇÃO, P. C. et al. Qualidade do solo em sistemas de manejo avaliada pela dinâmica da matéria orgânica e atributos relacionados. Revista Brasileira de Ciência do Solo, Viçosa, v. 29, n. 5, p. 777-788, 2005.

COSTA, C. C. A. et al. Produção de serapilheira na caatinga da Floresta Nacional do Açú - RN. Revista Brasileira de Biociências, Porto Alegre, v. 5, n. 1, p. 246-248, 2007.

DICK, P. D. et al. Química da matéria orgânica do solo. In: MELLO, V. F; ALLEONI, R. F (Eds.). Química e mineralogia do solo. 1. ed. Viçosa: SBCS, 2009, v. 2, cap. 1, p. 1-55.

FRAZÃO, L. A. et al. Estoques de carbono e nitrogênio e fração leve da matéria orgânica em Neossolo Quartzarênico sob uso agrícola. Pesquisa Agropecuária Brasileira, Brasília, v. 45, n. 10, p. 1198-1204, 2010.

GAldos, M. V.; CERRI, C. C.; CERRI, C. E. P. Soil carbon stocks under burned and unburned sugarcane in Brazil. Geoderma, Amsterdam, v. 153, n. 3, p. 347-352, 2009.

HE, Y. et al. Using light fraction and macroaggregate associated organic matters as early indicators for management-induced changes in soil chemical and biological properties in adjacent native and plantation forests of subtropical Australia. Geoderma, Amsterdam, v. 147, n. 3, p. 116-125, 2008.

IPECE. Instituto de Pesquisa e Estratégia Econômica 
do Ceará. Perfil básico municipal de Paraibapa, Disponível em: < http://www.ipece.ce.gov.br/ perfil_basico_municipal/2013/Paraipaba.pdf $>$.

Acesso em: 15 set. 2014.

JANZEN, H. H. et al. Light-fraction organic matter in soils from long-term crop rotations. Soil Science Society of America Journal, Madison, v. 56, n. 6, p. 1799-1806, 1992.

LEITE, L. F.C. et al. Estoques totais de carbono orgânico e seus compartimentos em argissolo sob floresta e sob milho cultivado com adubação mineral e orgânica. Revista Brasileira de Ciência do Solo, Viçosa, v. 27, n. 5, p. 821-832, 2003.

LOSS, A. et al. Carbono, matéria orgânica leve e frações oxidáveis do carbono orgânico sob diferentes sistemas de produção orgânica. Comunicata Scientiae, Teresina, v. 1, n. 1, p. 57-64, 2010.

LUCA, E. F. et al. Avaliação de atributos físicos e estoques de carbono e nitrogênio em solos com queima e sem queima do canavial. Revista Brasileira de Ciência do Solo, Viçosa, v. 32, n. 2, p. 789-800, 2008.

MUJURU, L. et al. Land use and management effects on soil organic matter fractions in Rhodic Ferralsols and Haplic Arenosols in Bindura and Shamva districts of Zimbabwe. Geoderma, Amsterdam, v. 209, n. 5, p. 262-272, 2013.

NASCENTE, A. S.; LI, Y. Y.; CRUSCIOL, C. A. C. Cover crops and no-till effects on physical fractions of soil organic matter. Soil and Tillage Research, Amsterdam, v. 130, n. 1, p. 52-57, 2013.

PEREIRA, M. G. et al. Carbono, matéria orgânica leve e fósforo remanescente em diferentes sistemas de manejo do solo. Pesquisa Agropecuária Brasileira, Brasília, v. 45, n. 5, p. 508-514, 2010.

PINHEIRO, E. F.M. et al. Impact of pre-harvest burning versus trash conservation on soil carbon and nitrogen stocks on a sugarcane plantation in the Brazilian Atlantic Forest region. Plant Soil, Netherlands, v. 333, n. 1, p. 71-80, 2010.

RESENDE, A. S. et al. Efeito da queima da palhada da cana-de-açúcar e de aplicações de vinhaça e adubo nitrogenado em características tecnológicas da cultura. Revista Brasileira de Ciência do Solo, Viçosa, v. 30, n. 6, p. 937-941, 2006.

ROSCOE, R.; MACHADO, P. L. O. A. Fracionamento físico do solo em estudos da matéria orgânica. 1. ed. Dourados, MS: Embrapa Agropecuária Oeste; 2002. 86 p.
ROSSI, C. Q. et al. Frações lábeis da matéria orgânica em sistemas de cultivo com palha de braquiária e sorgo. Ciência Agronômica, Fortaleza, v. 43, n. 1, p. 38-46, 2012.

SANTOS, H. G. et al. Sistema Brasileiro de Classificação de Solos. 3. ed. Brasília, DF: EMBRAPA, 2013. 353 p.

SILVA, F. A. S.; AZEVEDO, C. A. V. Versão do programa computacional Assistat para o sistema operacional Windows. Revista Brasileira de Produtos Agroindustriais, Campina Grande, v. 4, n. 1, p. 71-78, 2002.

SILVA, F. C. Manual de análises químicas de solos, plantas e fertilizantes. 2. ed. Brasília, DF: EMBRAPA, 2009, 627 p.

SILVA NETO, H. F. et al. Produção de palhada por cultivares de cana-de-açúcar RB e CTC e potencial controle de plantas daninhas. Revista de Biologia e Ciências da Terra, São Cristóvão, v. 13, n. 1, p. 116 $-120,2013$.

SOUZA, E. D. et al. Alterações nas frações do carbono em um Neossolo Quartzarênico submetido a diferentes sistemas de uso do solo. Acta Scitiarum Agronomy, Maringá, v. 28, n. 3, p. 305-311, 2006.

THORBURN, P. J. et al. Changes in soil carbon sequestration, fractionation and soil fertility in response to sugarcane residue retention are sitespecific. Soil and Tillage Research, Amsterdam, v. 120, n. 1, p. 99-111, 2012.

VELDKAMP, E. Organic carbon turnover in three tropical soils under pasture after deforestation. Soil Science Society of American Journal, Madison, v. 58, n. 1, p. 175-180, 1994.

XAVIER, F. A. S. et al. Biomassa microbiana e matéria orgânica leve em solos sob sistemas agrícolas orgânico e convencional na chapada da Ibiapaba - CE. Revista Brasileira de Ciência do Solo, Viçosa, v. 30, n. 2, p. 247-258, 2006.

YEOMANS, J. C.; BREMNER, J. M. A rapid and precise method for routine determination of organic carbonic in soil. Comunicata Soil Science Plant Analisys, New York, v. 19, n. 13, p. 1476-1476, 1988. 